\title{
DE CELEIRO A CENÁRIO: VITIVINICULTURA E TURISMO NA SERRA GAÚCHA. ${ }^{1}$
}

\author{
Luis Fernando De Matheus e Silva*
}

\section{RESUMO:}

A Serra Gaúcha, mais especificamente os municípios de colonização italiana, desde o início do século XX é tida como a maior e mais conceituada área produtora de uva e de vinhos do Brasil. Nos últimos trinta anos, porém, uma série de mudanças afetou o mercado de vinhos, tornando-o mais competitivo e internacionalizado, levando as empresas ali instaladas a valorizar aspectos de sua produção que as diferenciassem e mantivessem sua posição de destaque no mercado nacional. Essa valorização do local e de suas particularidades, promovida num contexto de globalização neoliberal do capitalismo, resultou numa maior importância do turismo, que, neste momento e naquele lugar, passou a exercer um papel-chave, "azeitando" as engrenagens e ajudando no bom funcionamento do motor do capital. O presente artigo tem por objetivo principal fornecer um panorama geral acerca de algumas das recentes transformações socioespaciais advindas do turismo, em especial sobre as tentativas de fazer daquele espaço uma representação de si mesmo.

\section{PALAVRAS-CHAVE:}

Vitivinicultura; Turismo; Lugar; Cultura Popular; Serra Gaúcha.

\section{ABSTRACT:}

Since the beginning of the $20^{\text {th }}$ century, the Serra Gaúcha, especially the counties of "old" Italian settling, is considered the grape and wine biggest and best producing area in Brazil. During the last 30 years, a succession of changes has affected the wine market, turning it more competitive and internationalized, and has induced the companies established in the region to value some aspects of its production in order to distinguish themselves and keep their prominent position in the national market. The appreciation of the local and its peculiarities has taken place in a context of capitalist neoliberal globalization has resulted in a greater importance of the tourism, which starts to perform a key-role at the present, lubricating the gears and improving the functioning of the capital engine. The main objective of this article is provide a wide view about some of recent social and spacial transformations which came from tourism, specially those attempts of doing that space a representation of itself.

\section{KEY WORDS:}

Viticulture; tourism; place; popular culture; Serra Gaúcha.

Atuando no tempo livre de modo a torná-lo produtivo, o turismo é parte integrante (e atualmente fundamental) no processo de reprodução do capital, carregando consigo a história do processo de modernização ocidental e propondo a sua reprodução sobre novos termos. Sendo assim, não podemos apreendê-lo por si só e vê-lo como um simples objeto de análise - esse tipo de abordagem não é capaz de ir além das descrições superficiais. Devemos encarálo como resultado e condição de processos que vão além dele, encontrando-se em constante movimento (ALFREDO, 2003). 
Na porção de colonização italiana da Serra Gaúcha, os primeiros registros de atividades turísticas datam dos anos 1930, quando este lugar fazia parte do destino de veraneio dos habitantes de Porto Alegre, que buscavam no clima mais ameno e na tranquilidade do Planalto um alento para o calor e agitação do verão na capital riograndense. Entretanto, o grande desenvolvimento industrial e a forte urbanização, verificados durante as décadas de 1950, 1960 e 1970, fizeram com que o foco dos investimentos, públicos e privados, se voltasse à indústria e à agricultura, relegando ao turismo um papel secundário². Entre os anos 1970 e 1990, porém, em meio a um período de grandes mudanças na economia global, o turismo passou a ser novamente explorado, especialmente nos municípios produtores de uva e vinho, tornandose muito mais presente do que nos anos anteriores.

Neste período, a chegada das multinacionais, a introdução de novas variedades de uva, os altos investimentos em pesquisa e em capital fixo e a busca por novas áreas de produção de uvas, combinados, reestruturaram e modernizaram a vitivinicultura brasileira, em especial aquela do Rio Grande do Sul. Em meio a este contexto, algumas vinícolas instaladas na Serra Gaúcha (a mais antiga e importante área produtora de vinhos do país) - a partir da valorização das particularidades daquele lugar passaram a buscar elementos que pudessem ser utilizados para a extração de renda monopolista ${ }^{3}$ e dessa forma, garantir posições vantajosas em um mercado cada vez mais competitivo e internacionalizado.

Essa valorização se deu em duas frentes. Primeiro, a partir de determinados aspectos pedológicos e climáticos locais que, segundo o discurso, uma vez melhorados graças aos investimentos em tecnologia e pesquisa, garantiriam uvas propícias para a produção de certos tipos de vinhos. Além disso, as características naturais - únicas - também seriam responsáveis por produtos igualmente únicos e incomparáveis, afinal de contas, "ficam impregnadas nas características físicas e químicas da uva e do vinho as condições geográficas do território onde foram produzidos, especialmente, aquelas devidas ao clima e ao solo" (FALCADE, 1999 , p. 25).

Que o vinho traz consigo características do solo e do clima em que é produzido, não resta dúvidas, e é certo também que alguns lugares são melhores do que outros para a obtenção de produtos de qualidade. Contudo, não podemos esquecer da influência fundamental que o discurso exerce para as alegações monopolistas

Na prática, o que constatamos no negócio do vinho são diversos discursos concorrentes, todos com alegações diferentes e verazes sobre a singularidade do produto. No entanto, todas essas mudanças e vaivens discursivos, assim como muitas das mudanças e reviravoltas ocorridas nas estratégias para controlar o mercado internacional do vinho, possuem, em sua raiz, não apenas a busca do lucro, mas também a busca de rendas monopolistas. Nisso, a linguagem de autenticidade, originalidade, singularidade e qualidades irreplicáveis especiais avulta em abundância (HARVEY, 2005, p. 229).

$\mathrm{Na}$ Serra Gaúcha, uma das maiores expressões desta valorização do local pode ser encontrada no "Vale dos Vinhedos" - localizado entre os municípios de Monte Belo do Sul, Bento Gonçalves e Garibaldi. Naquele lugar, encontramse grandes e renomadas vinícolas que, associadas, iniciaram o processo para a obtenção de um selo de origem controlada para seus vinhos e o obtiveram em $2002^{4}$. Dessa maneira, a partir da representação de um lugar com "condições geográficas únicas", os vinhos produzidos no Vale dos Vinhedos, agora certificados, passaram a competir com mais igualdade com os vinhos importados. Alguns, inclusive, receberam prêmios e figuram em mercados no exterior ${ }^{5}$.

Mas não é somente a partir das características ecológicas que as empresas vinícolas da Serra Gaúcha têm buscado embasar o discurso de unicidade e tipicidade para seus produtos. Isso porque ali, o vinho, assim como a polenta ou o salame, ganha status de tradição 
cultural e as vinícolas lá instaladas, seja qual for seu tamanho e origem, para além das características naturais, utilizam-se do capital simbólico coletivo construído sobretudo em cima da imigração italiana para garantir e sustentar renda monopolista. "Trata-se de uma questão de determinar que segmentos da população devem se beneficiar mais do capital simbólico, para o qual todos, em seus próprios e distintivos modos, contribuíram" (HARVEY, 2005, p. 235). Por essa razão, podemos afirmar que as vinícolas passaram também a apoiar-se nos discursos da tradição e da cultura (especialmente aquela de raiz italiana e camponesa), utilizando-os como subsídios capazes de diferenciarem a produção daquele lugar em relação ao restante do país.

Portanto, à semelhança do que ocorre em outros lugares tradicionais de produção vinícola ao redor do planeta, na área produtora de uva e vinho da Serra Gaúcha, natureza e cultura locais, instrumentalizadas e pensadas enquanto recursos, tiveram seus usos, valores e significados expandidos para as esferas política e econômica. Pois, como bem nos lembra David Harvey:

Se as alegações de singularidade, autenticidade, particularidade e especialidade sustentam a capacidade de conquistar rendas monopolistas, então sobre que melhor terreno é possível fazer tais alegações do que no campo dos artefatos e das práticas culturais historicamente constituídas, assim como no das características ambientais especiais (incluindo, é claro, os ambientes sociais e culturais construídos)? (HARVEY, 2005, p. 232)

Mas, na esteira da globalização, as particularidades do local, tão necessárias à sobrevivência corporativa nestes tempos neoliberais, além de garantir as sonhadas vantagens monopolistas às empresas vinícolas, fazem das regiões produtoras de uva e de vinho verdadeiros lugares "mágicos". E esta criação ideológica e fantástica dos lugares geralmente vem acompanhada do incremento de outro fenômeno - o turismo.

O turismo, sob condições de mercado extremamente competitivas, além de ajudar a sustentar e divulgar a imagem do lugar e de seus produtos, possibilita às vinícolas, ao abrirem restaurantes, pousadas etc., diversificarem e ampliarem seu leque de atividades, favorecendo a acumulação de capital. Ou seja, "cada vez mais o espaço, produzido como mercadoria, entra no circuito da troca, atraindo capitais que migram de um setor da economia para outro de modo a viabilizar a reprodução [do capital]" (CARLOS, 2001, p. 16).

As relações entre o processo de produçãodesenvolvimento das forças produtivas, produzem no mundo moderno, novas possibilidades de realizar a acumulação, que em sua fase atual, liga-se cada vez mais à produção do espaço - produção que se coloca numa nova perspectiva, onde novos lugares ganham valor de uso (...) todavia a contradição entre o processo de produção social do espaço e sua apropriação privada está na base do entendimento da reprodução espacial hoje (CARLOS, 2001, p. 64).

Dessa forma, é preciso ter claro que o incremento do turismo na área de produção vitivinícola da Serra Gaúcha, antes de mais nada, é tanto decorrência como necessidade do desenvolvimento capitalista globalizado e neoliberal e, apesar de não ser um fenômeno exclusivo das últimas três décadas, por diversas razões, é neste momento que ganha força. Entretanto, seria uma conclusão demasiadamente reducionista considerar que o incremento do turismo, nestes anos, é decorrência exclusiva das necessidades da indústria vitivinícola.

Num mundo em que a competitividade se coloca de maneira cada vez mais forte e generalizada, os próprios lugares, municípios e regiões têm atuado sob a lógica do mercado e, através do uso do capital simbólico coletivo, tentam criar uma imagem positiva e diferencial de si mesmos, garantindo, dessa forma, vantagens competitivas em relação aos seus "concorrentes". "O que está em jogo é o poder do capital simbólico coletivo, isto é, o poder dos marcos especiais de distinção vinculados a algum lugar, dotados de um poder de atração importante em relação aos fluxos de capital de modo mais 
geral" (HARVEY, 2005, p. 233). Além disso, precisamos ainda levar em consideração que durante este período, acompanhando a valorização das localidades, o surgimento de novos negócios e a profusão de gostos e modas engendrados pelo capitalismo neoliberal, ocorre uma diversificação nas maneiras de praticar turismo - capazes de atingir os mais variados públicos e lugares.

Considerada "área prioritária" para o incremento do turismo em nível nacional, a Serra Gaúcha, desde o final dos anos de 1990 e início dos anos 2000, através do Programa de Desenvolvimento do Turismo no Sul do Brasil PRODETUR SUL, que conta com financiamento do Banco Interamericano de Desenvolvimento (BID) e o Banco do Brasil como mutuário e agente financeiro, tem sido palco de diversas ações para fomentar a atividade turística.

\begin{abstract}
No Estado do Rio Grande do Sul, a estratégia geral é a de captar maior número de turistas de fora do estado por meio de um composto mercadológico capaz de aumentar o valor turístico do destino da área prioritária (Serra Gaúcha), criando dentro dela capacidades produtivas especializadas de forma a contribuir para o desenvolvimento sustentável, através da geração de divisas, emprego e renda, desdobrando-se em uma série de estratégias específicas, conforme as categorias de estratégias nacionais (PROTETUR-SUL, 2004, p. 8).
\end{abstract}

Valendo-se disso e aproveitando as características culturais e naturais da porção colonizada por italianos, o Estado, em conjunto e a favor dos interesses econômicos dominantes na chamada "Região Uva e Vinho", a partir da década de 1990, passou a estimular o crescimento de modalidades de turismo como o "Enoturismo" e o "Turismo Rural", vendendoos como alternativas para o "desenvolvimento sustentável" dos municípios que a integram. Assim, ao passo que possibilita ampliar e diversificar as possibilidades de acumulação e reprodução do capital, o turismo fornece e fortalece os discursos de preservação (tanto da natureza como da tradição e da cultura popular) e de "sustentabilidade", tão em moda nos dias de hoje.

Assim, indústrias vinícolas, empresários, poder público e, até mesmo camponeses, cada qual à sua maneira, através do turismo, vêm se aproveitando do capital simbólico e cultural engendrados pela imigração italiana e também das paisagens agrárias encontradas na região como forma de atrair visitantes e ampliar as possibilidades de geração de lucro ou renda, o que implica transformações substanciais nas formas pelas quais aquele espaço geográfico tem sido (re)produzido.

Mas, lembremos que o "lugar turístico" tem que ser antes construído na cabeça das pessoas, ou seja, é preciso criar uma ideia (atraente) acerca dele e isso é feito, na maior parte dos casos, a partir da pasteurização e da massificação de algumas de suas características naturais, sociais e culturais. Essa construção é realizada com esmero pelos "mestres de obra" da mídia e da comunicação - operários habilidosos à serviço do capital. Estes, apoiando-se no discurso ideológico construído ao longo dos anos pelos estudos e etnografias "oficiais" 6 sobre a imigração italiana, acabam por ajudar a difundir uma imagem romantizada e idílica do campo e dos colonos ítalo-brasileiros da Serra Gaúcha.

\section{A propaganda, como um dos componentes do marketing turístico, é fator de projeção dos atributos naturais, culturais e históricos inseridos em roteiros, que aliados aos serviços de hospedagem e transportes compõem os tradicionais pacotes turísticos. A linguagem da propaganda turística é feita de termos que evocam beleza, sedução, harmonia, descontração e felicidade. Em síntese, o discurso comercial do turismo, que busca seduzir o cliente, é a linguagem dos prazeres das viagens, da oportunidade de desfrutar de lugares paradisíacos, tendo em vista a plena satisfação dos cinco sentidos (TOMAZZONI, 2006, p. 347).}

Tal como o fotógrafo (e com a ajuda deles, é claro), o capital seleciona os melhores ângulos e poses da Serra Gaúcha e, a partir das lentes do 
turismo, o que vemos é a aparição de um lugar único e "abençoado" - um verdadeiro "pedaço da Europa no Brasil", ou ainda, "o Brasil que deu certo". Esta imagem construída de um espaço agrário "puro", "natural" e "próspero" resulta da abolição das diferenças e de uma simplificação orquestrada da realidade e é justamente este lugar "imaginário", construído pela mídia e pelos promotores do turismo (sejam eles vinícolas, hotéis, agências de turismo, poder público e mídia), que chamamos de "cenário". Nele, as formas são tomadas pelo conteúdo e a realidade é reduzida à sua interpretação, ou seja, segundo os gostos e necessidades do desenvolvimento capitalista. Telenovelas, filmes, vídeos promocionais, reportagens de revistas, jornais, festas e festivais "típicos", quase tudo concorre para a produção imaginária (e espetacular) acerca daquele lugar.

A mídia, nesse caso, tem um papel cada vez mais importante, produzindo signos do bem estar, de satisfação e da felicidade pelo ato de consumo de lazer. O que prova que há momentos que a informação é mais importante que o conhecimento. (...) A manipulação das pessoas não pode ocorrer sem o desenvolvimento dos meios de comunicação que 'fazem acontecer' e que promovem a valorização dos lugares de praias, de montanhas, de cidades ou de lugares na cidade, bem como um modo de freqüentá-los (CARLOS, 2001, p. 69).

Para ilustrar o argumento aqui exposto, selecionamos alguns trechos de uma reportagem feita pela revista Veja (outubro/2007) sobre a Serra Gaúcha, em que, recheado por um forte componente ideológico, o lugar, sob a alcunha de "Vale da Felicidade", é retratado como um Éden não há pobreza, feiúra, violência e o mundo parece que parou.

"A uma hora de carro de Porto Alegre, no Rio Grande do Sul, um punhado de cidades abriga cerca de 660.000 pessoas que desfrutam e preservam, geração após geração, um alto padrão de qualidade de vida. É um pedaço do Brasil onde os índices de pobreza são tão baixos quanto os da Inglaterra, os analfabetos são tão difíceis de encontrar quanto no Canadá e vivese mais tempo e com tanta saúde quanto os idosos de um país europeu como a Bélgica. O custo de vida ali ainda é baixo, os serviços públicos funcionam e as pessoas não se sentem inseguras por morar em casas sem muro. Nesse Brasil não tem fila. Em postos públicos de saúde, a consulta começa com o médico acionando seu computador para levantar o histórico do paciente" (...)

"Além da boa escolaridade, algo que certamente conta a favor desse próspero Brasil é o fato de sua economia ser menos dependente do estado que a dos demais municípios brasileiros. (...) É o setor privado, portanto, o principal motor dessas economias. Parte do empreendedorismo local remete aos primórdios da região. Ao contrário dos colonizadores portugueses, que viviam numa economia monopolizada pelo estado, os imigrantes que chegaram ao Sul tinham em seu respectivo país mais chances de tentar a vida por conta própria. E eles faziam isso. Quando vieram ao Brasil, estavam justamente atraídos pela possibilidade de comprar terras por bons preços - e passaram aos filhos essa espécie de DNA para os negócios" (...)

(...) "Em suma, tudo se passa num Brasil em que a mão-de-obra é mais qualificada, trabalha-se mais duro e ainda por cima o sistema produtivo é organizado por instituições alheias ao estado. Diz o economista Marcelo Neri, da FGV: "Estamos diante de um raro exemplo no Brasil de sociedade que conseguiu articular-se de modo eficiente". (...) Nem todas as condições que deram origem ao vale da felicidade gaúcho podem ser repetidas em outras regiões. Sua tradição cultural, por exemplo, é irrepetível. Mas há ali um punhado de lições que ajudariam muito a harmonizar a vida urbana no Brasil caso fossem seguidas".

Com fotografias bonitas, vídeos e textos cativantes, o sítio na internet da Associação de produtores de Vinhos Finos do Vale dos Vinhedos (Aprovale) ${ }^{7}$ também nos fornece um ótimo exemplo de como é feita a manipulação ideológica acerca da realidade daquele lugar. 
"O aroma adocicado da uva. O sabor do vinho. Os segredos de um enólogo. Os mistérios da natureza. O Vale dos Vinhedos é um lugar consagrado ao lado bom da vida. Aqui, foram semeadas uvas de castas nobres que depois de transformadas deram origem a vinhos finos, hoje reconhecidos em todo o Brasil e no exterior pela sua qualidade".

"O legado histórico e cultural deixado pelos imigrantes italianos está enraizado nas pessoas, seus costumes e, até mesmo, na paisagem do Vale dos Vinhedos. A construção de capelas, a devoção aos santos, o dialeto vêneto e, principalmente, o cultivo da videira e a produção do vinho são marcas da imigração. Sendo o vinho um elemento tradicional de sua cultura, os italianos trouxeram as mudas de videiras quando para cá vieram".

"O turismo é um grande meio de divulgação da cultura, do trabalho e da história de um povo. O Vale dos Vinhedos oferece um variado roteiro turístico, que vai desde passeios pelas vinícolas, degustação de vinhos até jantares típicos com animação de corais, servido em meio ao ambiente pitoresco e aconchegante das cantinas. Tudo isso é oferecido pelas próprias famílias que vêm resgatando e mantendo a hospitalidade e os costumes de seus antepassados, preservando desta forma a cultura dos imigrantes italianos (...). Visitar - Vale dos Vinhedos é penetrar no coração da história italiana e vivenciar, através dos monumentos e do ambiente sugestivo, um passado relativamente jovem" (...).

O patrimônio cultural trazido com a imigração italiana é colocado em primeiro plano e, ao integrar-se ao turismo, adquire um novo uso - o econômico. Nesse processo, a história perde suas contradições e é pasteurizada até ficar palatável para o gosto dos promotores da ilusão. As dificuldades de adaptação à nova terra, os anos de penúria e sofrimento servem apenas para simplesmente acentuar uma suposta qualidade empreendedora do imigrante europeu e legitimar politicamente a burguesia surgida das colônias.

Agora, esses ingredientes servem também para temperar as estórias e aguçar a imaginação dos visitantes que por lá têm chegado. "O turismo é sobre a invenção e reinvenção de mitos coletivos, e nessa medida, é uma forma de produção cultural, com implicações econômicas, políticas e sociais profundas" (Peralta, 2003, p. 95). O vinho, a música, a alegria, a comida farta e a riqueza da região, para os turistas e possíveis visitantes, leitores das revistas e dos jornais, esta é a imagem que fica da área vitivinícola da Serra Gaúcha. Se falam da pobreza, ela se refere ao passado e o lugar, fruto de um "povo vitorioso e feliz", é maquiado de forma a parecer um paraíso terrestre ${ }^{8}$.

A história torna-se memória e comemoração, depois cultura, depois folclore (...) os signos da história derrotada, a evocam ou invocam (...). Os signos da felicidade se generalizam. Um certo sorriso une o ético ao estético no mundo da mercadoria. Atenção: os signos da felicidade não evocam a felicidade, são a felicidade. Você não tem outra felicidade que o uso dos signos (LEFEBVRE apud CARLOS, 2001, p. 67).

Estes construtores da história geográfica do capitalismo "esquecem" de mencionar que se as diferenças sociais na região não são tão gritantes quanto àquelas encontradas na maior parte do Brasil, isto se deve, em primeiro lugar, ao estabelecimento da pequena propriedade camponesa no final do século XIX, ou seja, graças a uma distribuição mais igualitária da terra9 .

Além do mais, é desnecessário dizer que ignoram o fato de que o desenvolvimento econômico capitalista, como em qualquer lugar, não se deu sem gerar contradições. A industrialização e a urbanização, ocorridas a partir dos anos 1960 e 1970, foram responsáveis por um aumento considerável na pobreza e na proliferação de subabitações, sobretudo na periferia de cidades com Bento Gonçalves e Caxias do Sul. Sem contar na exploração vivida pelos colonos $^{10}$ e o fato de que, no mesmo período, a falta de terras e as condições insatisfatórias de vida no campo fizeram com que muitos destes pequenos agricultores ficassem impossibilitados de reproduzir sua condição enquanto pequenos proprietários $^{11}$. 
Portanto, o discurso (criado pela elite, apropriado e difundido pela mídia e pelo turismo) de que os descendentes de europeus, graças ao árduo trabalho e à sua "inata" superioridade prosperaram no Brasil, construindo cidades ricas e trazendo progresso onde antes só havia "mato e índio", além de ser um tanto racista, escamoteia os conflitos e joga para debaixo do tapete as sujeiras produzidas pelo desenvolvimento capitalista. ${ }^{12}$

De toda maneira, como o poder do discurso é essencialmente poder simbólico, que "é um poder de fazer coisas com as palavras" (BOURDIEU, 1990 , p. 167), o discurso criado sobre a Serra Gaúcha, em especial acerca da porção colonizada por italianos - produtora de uva e vinho - tem ajudado a transformar esta num dos principais pólos de turismo do sul do país.

E uma vez criado no imaginário coletivo, o "cenário" acaba inscrevendo-se no espaço e a reestruturação espacial promovida pelo turismo, além de encontrar novos sentidos para antigas materializações, promove também a espetacularização ${ }^{13}$ dos lugares e a proliferação de simulacros, demonstrando, desta maneira, que "o poder nos reinos da representação pode terminar tendo tanta relevância quanto o poder sobre a materialidade da própria organização espacial" (HARVEY, 2000, p. 113).

Sem exceção, trata-se de espaços dominados por estratégias de marketing e que só têm o sentido que Ihe é conferido pelo marketing na medida em que são vistos como uma imagem e um signo de bem estar e felicidade que apaga a sua configuração de mercadoria, mas é redutor da realidade que pretende representar. Lugares cada vez mais visuais, que invadem a vida das pessoas através do marketing, tornando-se lugares do desejo (CARLOS, 2001, p. 68).

O Vale dos Vinhedos (mais uma vez) fornece valiosas pistas para compreendermos a produção espetacular do espaço advinda do turismo, bem como a utilização do patrimônio cultural e do capital simbólico neste movimento, isto porque, considerado estratégico pelas empresas produtoras de bebidas instaladas por ali, o turismo é parte integrante do processo que levou à criação do selo de procedência geográfica para seus vinhos. Naquele lugar, o espaço do turismo tem sido produzido a partir de uma combinação entre natureza privilegiada, sofisticação, modernidade capitalista e tradição cultural dos colonos italianos (que fornece signos de autenticidade) - uma mescla "pós-moderna" 14 que ajuda a dissolver as contradições e fortalecer a ideologia de "um lugar diferenciado, com gente e produtos igualmente diferenciados".

\begin{abstract}
"Num vale mágico que corre por entre as divisas de Bento Gonçalves, Garibaldi e Monte Belo do Sul, logo que o imigrante italiano estendeu suas latadas e espaldeiras pelas altas encostas circundantes, entendeu estar numa região privilegiada por um clima consagrado ao cultivo da vinha. Trabalhou, então a terra, e a ela entregou as mais finas castas que desenvolveram-se naturalmente e o lugar tornou-se o Vale dos Vinhedos. E de forma natural, também, assumiu o ato pioneiro de estabelecer-se como a primeira região demarcada com o selo de Origem Controlada do país". 15
\end{abstract}

Mas, apesar da referência às raízes italianas, a inspiração vem mesmo da Califórnia, especialmente de Nappa Valley - um dos pólos vinícolas mais capitalizados do mundo. Ao melhor estilo "Sideways" ${ }^{16}$, os visitantes podem conhecer as grandes vinícolas instaladas por lá (as mesmas que exibem propaganda nas revistas de maior circulação do país), passear entre seus parreirais, ajudar a colher uva, degustar os diferentes tipos de vinho e, depois, comer um belo jantar italiano num chique restaurante, ou, se preferirem, polenta com galeto numa "genuína casa de colônia".

Simulacro da Europa, cópia dos Estados Unidos, mas localizado na região nordeste do Rio Grande do Sul, quanto mais próximo das grandes vinícolas, mais espetacular o Vale dos Vinhedos se torna - belos vales repletos de parreirais, serpenteados por um caminho de paralelepípedo, com ruas arborizadas e canteiros floridos nas janelas das casas, onde vez ou outra se avista 
um pequeno bosque com araucárias. Paisagens encantadoras que figuram o imaginário coletivo acerca da Serra Gaúcha - o cenário (quase) tornado realidade.

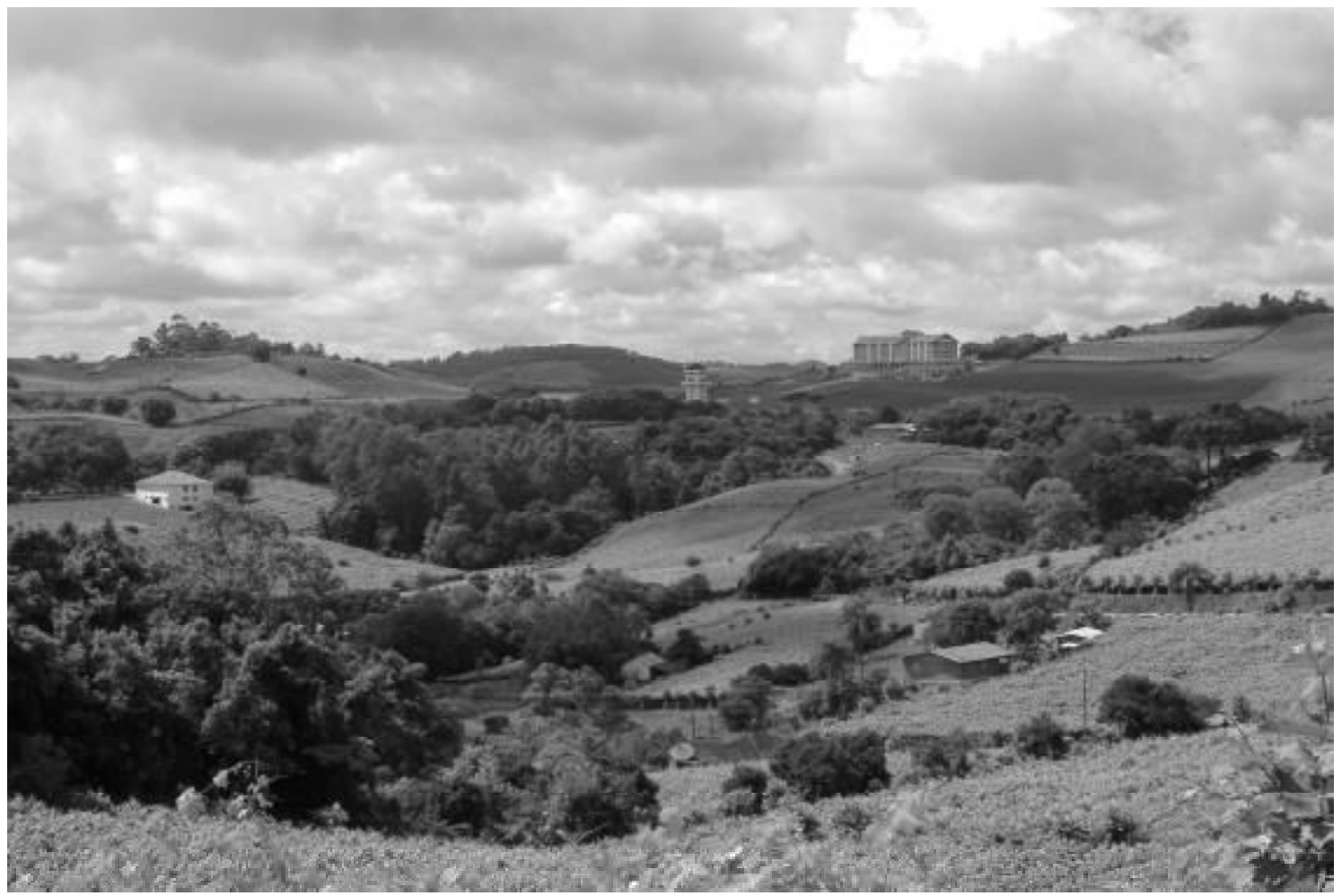

Vale dos Vinhedos: Ao fundo, a Vinícola Miolo e o Spa "Villa Europa".

Foto: outubro/ 2007, autoria própria.

Geralmente, este espaço produzido pelo e para o turismo aponta para a vitória do valor de troca sobre o valor de uso, ligando-se "diretamente, ao plano do consumo do espaço enquanto lugar da acumulação, articulado às necessidades de reprodução da sociedade (...). O espaço-mercadoria se impõe na vida cotidiana enquanto valor de troca que submete o modo e o tempo do uso" (CARLOS, 2001, p. 70).

Torna-se claro, portanto, que a adequação confessadamente urbana ao rural reinstitui sob nova forma uma subordinação do rural, além disso, vale dizer que, ao produzir um espaço urbano nisso que tem se chamado de rural, transforma o próprio rural, com suas características naturais, em representação de si mesmo (ALFREDO, 2003, p. 39).
Mas, como o processo de reprodução espacial se articula ao plano da reprodução da vida, o movimento que procura transformar aquele espaço agrário em um cenário não elimina o fato de que ali ainda é lugar onde a vida acontece para seus moradores - usadores e não usuários do espaço (CARLOS, 2001). Em outras palavras, o "cenário" também é espaço vivido para aqueles que o habitam, comportando, portanto, duas lógicas distintas - aquela criada para o visitante e aquela vivida pelo habitante, "para quem o espaço se reproduz enquanto lugar onde se desenrola a vida em todas as suas dimensões - o habitar e tudo que ele implica/revela" (CARLOS, 2001, p. $65)$. 


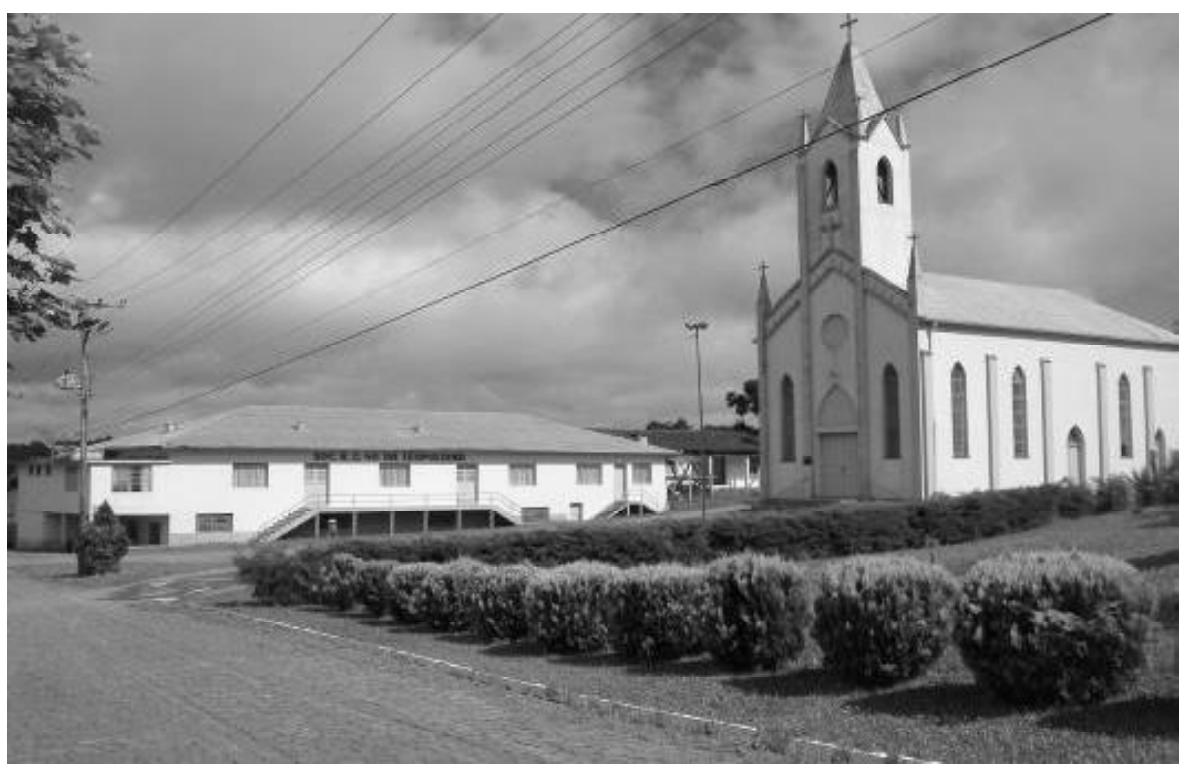

Centro da comunidade 40 da Leopoldina, localizada no Vale dos Vinhedos, próxima à vinícola Miolo. Vias pavimentadas e preocupação estética com a produção dos lugares do turismo. Foto: outubro/2007, autoria própria.

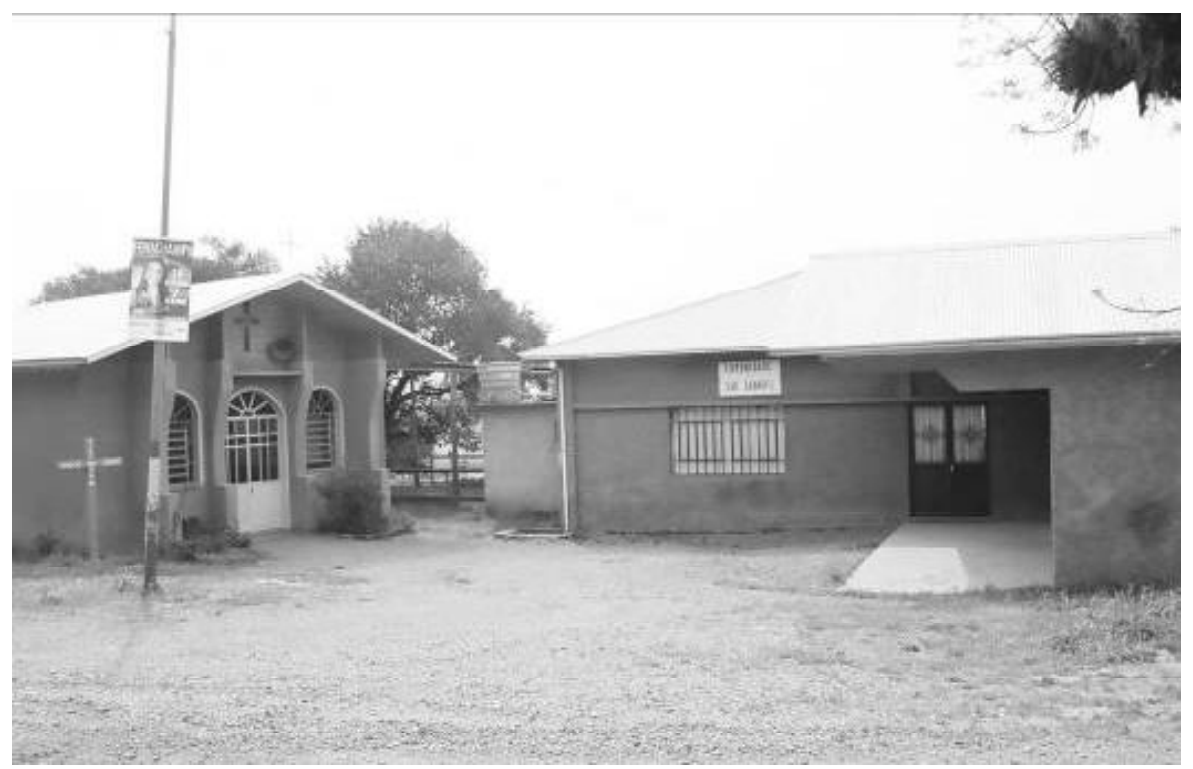

Não muito longe dali, a Comunidade São Gabriel - onde a Vinícola Miolo também mantém parreirais próprios - com construções que mantêm um padrão estético muito mais simples.

Foto: Setembro/2007, autoria própria. 


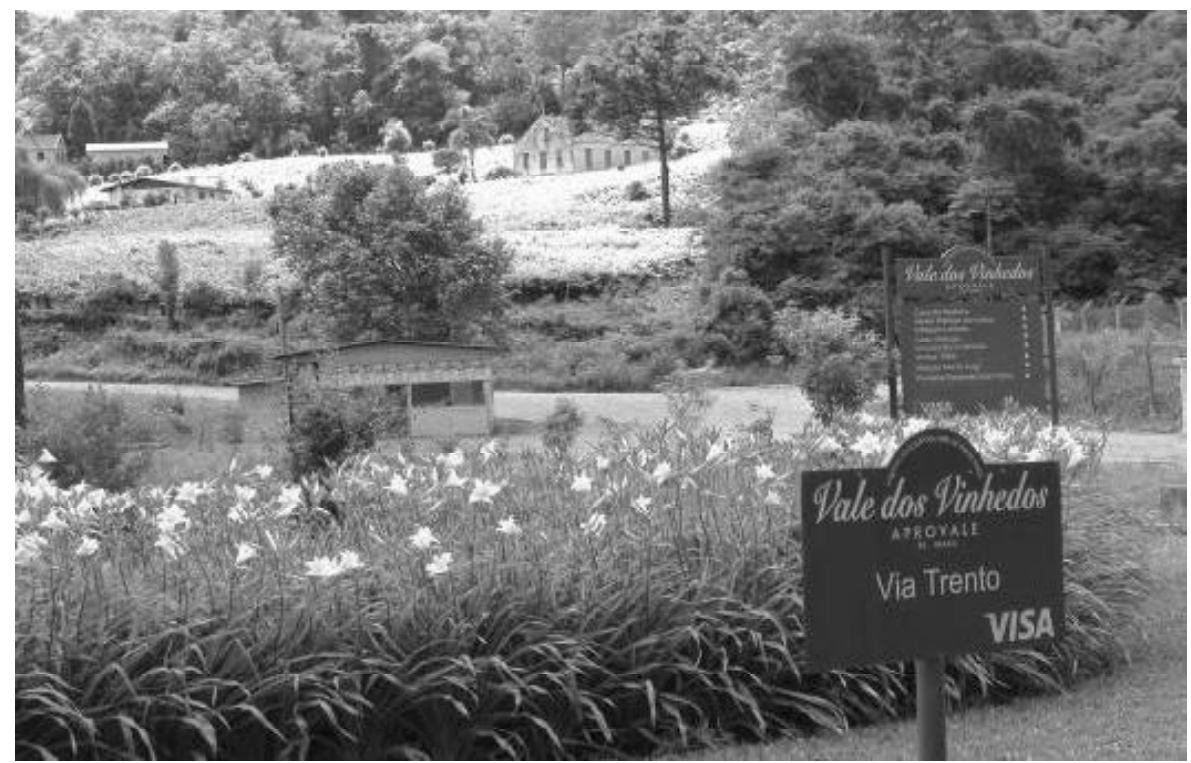

Comunidades embelezadas, sinalizadas e pavimentadas no Vale dos Vinhedos. Num segundo plano, à esquerda, um pequeno bar e mercearia, destinado a abastecer os moradores da linha. Foto: outubro/2008, autoria própria.

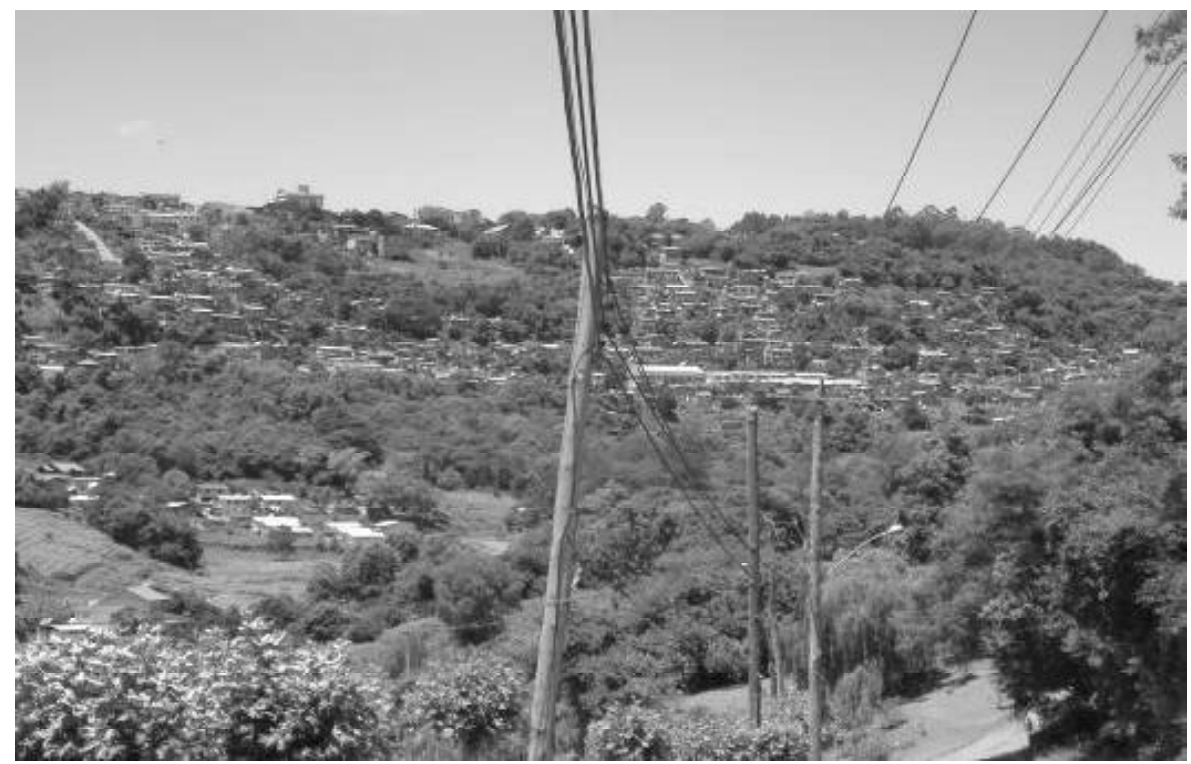

Mas por mais que o discurso ideológico e a propaganda tentem disfarçar, o visitante mais atento percebe que "nem tudo são flores" (ou melhor, uva, vinho, riqueza e felicidade) na Serra Gaúcha. A favela que cresce próxima ao Vale dos Vinhedos, na cidade de Bento Gonçalves, demonstra que o desenvolvimento econômico, sob o capitalismo, não se dá sem gerar conflitos e contradições. Foto: novembro/2008, autoria própria. 
Apesar de não serem os únicos moradores do lugar, os camponeses são os que mais sentem as transformações advindas da valorização mercadológica do espaço agrário na área produtora de uva e vinho da Serra Gaúcha, desencadeada pelo atual estágio de desenvolvimento capitalista. Essas modificações não são percebidas somente nas comunidades, nas linhas ou nos espaços de consumo e lazer criados pelas empresas, pois dentro da própria unidade familiar, ainda que em menor escala, o turismo engendra modificações.

Em nível nacional, desde os anos 1990, mas sobretudo a partir dos anos 2000, o Estado tem incentivado o turismo rural junto aos camponeses, acreditando ser esta uma atividade que possibilita fomentar o desenvolvimento local. Para o Ministério do Desenvolvimento Agrário (MDA), dentro dos fundamentos do Programa Nacional para o Fortalecimento da Agricultura Familiar (PRONAF), o "Turismo Rural na Agricultura Familiar" seria:

A atividade turística que ocorre na unidade de produção dos agricultores familiares que mantêm as atividades típicas da agricultura familiar, dispostos a valorizar, respeitar e compartilhar seu modo de vida, o patrimônio cultural e natural, ofertando produtos e serviços de qualidade e proporcionando bem estar aos envolvidos (MDA, 2003). ${ }^{17}$

Os municípios da Serra Gaúcha, por sua vez, dentro dos princípios e objetivos do programa de regionalização do turismo representado pelo PRODETUR-SUL - que priorizam "áreas com alto grau de atratividade natural, cultural e étnica, buscando nelas alcançar a condição de destino turístico consolidado" (PRODETUR SUL, 2004, p. 7), também têm procurado estimular ações que "preservem suas tradições" e fomentem o turismo rural junto aos pequenos agricultores.

Do lado dos colonos - os mesmos que construíram aquelas paisagens e são produtores da cultura que é vendida, hoje, como parte do "cenário" turístico - as constantes crises e dificuldades enfrentadas para manterem a família reunida trabalhando no campo, fizeram com que, nas últimas décadas, muitos deles deixassem de ser meros produtores de matéria-prima para as empresas produtoras de bebidas e passassem a retomar a fabricação artesanal de determinados produtos como sucos, vinhos e geléias. Assim, a partir da necessidade de incrementar a renda familiar, divulgar sua produção artesanal e contando com o apoio e incentivo do poder público, o turismo acabou entrando no cotidiano de muitas famílias camponesas da Serra Gaúcha, que abriram as portas de sua propriedade à visitação, e, dessa forma, contribuíram para que sua cultura e seu modo de vida ganhassem outros significados.

Nesse sentido, o roteiro turístico "Estrada do Sabor", desenvolvido pela Prefeitura de Garibaldi, por meio da Secretaria de Turismo, Indústria e Comércio, em conjunto com os agricultores e o apoio do Serviço Brasileiro de Apoio às Micro e Pequenas Empresas (Sebrae) e da Empresa de Assistência Técnica e Extensão Rural do Estado do Rio Grande do Sul (Emater/ RS), é bastante elucidativo. Elaborado em 2001, o roteiro envolve seis famílias estabelecidas em diferentes comunidades do interior do município que têm na agricultura e na pequena produção agroindustrial suas principais fontes de renda.

$\mathrm{Na}$ "Estrada do Sabor" não há hospedagem nas propriedades rurais, apenas a interação dos turistas com os agricultores através da gastronomia, estórias e venda de produtos "típicos". Para incentivar a continuidade na produção agrícola e artesanal, foi estabelecido através das reuniões entre os integrantes do roteiro, que cerca de $70 \%$ dos produtos comercializados deveriam ser plantados e produzidos no local. Ivane Fávero, ex-secretária de turismo de Garibaldi, coordenadora do curso de Enoturismo da Faculdade de Integração do Ensino Superior do Cone Sul - Fisul e uma das idealizadoras do roteiro, explica:

Como a idéia foi trabalhar com famílias que tivessem o interesse espontâneo em participar, o projeto não obedece a um caminho, um roteiro único, como comumente se observa nas propostas de turismo rural, e se situou em seis localidades diferentes. Cada uma das 


\section{propriedades possui características} diferenciadas, no que tange à localização, estrutura e a usos e costumes da família. O que se buscou foi trazer presente a história da família, seu modo de vida, suas receitas, os utensílios e equipamentos utilizados, para compor a atratividade da propriedade (FÁVERO, 2004, p. 32).

À semelhança do que acontece em outros lugares da Serra Gaúcha, os folhetos e reportagens sobre o roteiro da "Estrada do Sabor", têm procurado construir uma imagem fantasiosa acerca do lugar e dos colonos - como se estes fossem verdadeiros "museus vivos" ${ }^{18}$. "O retorno passadista, portanto, restaura o rural numa imagem idílica, sobre um espaço urbano que realiza a 'escassez' do natural como nova mercadoria" (ALFREDO, 2003, p. 39). Isso porque, conforme indica Canclini:

O mundo moderno não se faz apenas com aqueles que têm projetos modernizadores. Quando cientistas, tecnólogos e empresários buscam seus clientes, eles têm que lidar com a resistência à modernidade. Não apenas pelo interesse em expandir o mercado, mas também para legitimar sua hegemonia, os modernizadores precisam persuadir seus destinatários de que - ao mesmo tempo que renovam a sociedade - prolongam tradições compartilhadas. Posto que pretendem abarcar todos os setores, os projetos modernos se apropriam dos bens históricos e das tradições populares (CANCLINI, 2006, p. 159).

O folder destinado a divulgar as atrações turísticas de Garibaldi, bonito e muito bem feito, convida os visitantes a se sentirem parte da família camponesa, enquanto se aquecem no fogão à lenha. Já o vídeo que promove a imagem do município, assim se refere ao roteiro:

"A Estrada do Sabor encanta também pela paisagem interiorana, onde capitéis, capelas, vinhedos e vales compõem quadros de rara beleza. As práticas de agricultura ecológica, degustação de vinhos, sucos, pães, queijos e salames, receitas antigas de família. Tudo isso, contado com o carinho de um povo vocacionado e treinado para bem receber" (...)

"(...) Na Estrada do Sabor, é claro que o turista encontra a típica mesa italiana, sempre farta e com a presença marcante do vinho" (vídeo: Garibaldi 107 anos - orgulho de ser daqui). ${ }^{19}$

E para atender aos anseios dos turistas, vindos sobretudo de grandes centros urbanos e que procuram na colônia o caráter simbólico das "imagens" e "objetos" do passado que Ihe são oferecidos e que representam um mundo definitivamente perdido e irrepetível (PERALTA, 2003), os colonos fizeram cursos e foram atrás daquilo que eles tinham na propriedade e que poderia ser utilizado como atrativo turístico. "A gente não procurou novidades, coisas, digamos assim, modernas. Como aqui é turismo rural, a gente se aperfeiçoou em cima do tradicional". ${ }^{20}$

O turista procura recapturar os totens de um tempo e de um mundo que idealiza como míticos, aos quais ele já não pertence. Um mundo e um tempo pré-modernos, cuja autenticidade deriva da sociabilidade dos seus residentes, imaginados pelo turista para refazer a perda dos referentes simbólicos que a modernidade lhe negou. Move-se, em suma, em busca do "outro autêntico", procurando encontrar nesse processo o "eu autêntico" (SELWYN, 1996, p. 89), que existe na imaginação do turista. Se esse "outro autêntico" não existe, ou se existe de forma difusa, há que, senão "inventá-lo", pelo menos "recriá-Io" (PERALTA, 2003, p. 89).

Assim, as forças que movem o capital, a partir do turismo e num "contexto de uma sociedade 'pós-tradicional' nostálgica e carente de elementos de identificação coletiva" (PERALTA, 2003), procuram acentuar determinados "costumes" e "tradições" encontrados no seu interior - tidos como mais "puros" e "naturais", representantes de um grupo que mantém a unidade familiar e a vida em comunidade como pilares centrais de sua existência e reprodução conferindo-Ihes um novo uso, o econômico. "A ironia é que a tradição é agora preservada com freqüência ao ser mercadificada e comercializada como tal" (HARVEY, 2005, p. 273). 
Por outro lado, é preciso deixar claro que essa imagem romanceada, passadista e estática, criada pela mídia e pela propaganda, de alguma maneira, é apropriada pelo morador local. O apego à tradição e ao discurso que enaltece sua cultura parece confortar os agricultores num momento em que as transformações engendradas pelo desenvolvimento da sociedade capitalista e moderna se fazem cada vez mais presentes no interior da colônia.

o impulso de preservar o passado é parte do impulso de preservar o eu. Sem saber onde estivemos, é difícil saber para onde estamos indo. O passado é o fundamento da identidade individual e coletiva; objetos do passado são a fonte da significação como símbolos culturais. A continuidade entre passado e presente cria um sentido de seqüência para o caos aleatório e, como a mudança é inevitável, um sistema estável de sentidos organizados nos permite lidar com a inovação e a decadência. O impulso nostálgico é um importante agente do ajuste à crise, é o seu emoliente social, reforçando a identidade nacional quando a confiança se enfraquece ou é ameaçada (HEWISON apud HARVEY, 2000, p. 85).

Mais do que isso, em muitos casos, o "resgate do passado" e a "preservação das tradições", ainda que estimulados pela sua feitichização e consequente transformação em mercadorias, devem ser vistos como uma das diversas estratégias camponesas para, em meio às mudanças econômicas, assegurar a reprodução de sua condição de pequeno proprietário da terra. Dessa forma, estes agricultores, ao passo que buscam alternativas que possam contribuir para aumentar e complementar a renda familiar, demonstram sua capacidade para reativar criativamente e, até mesmo, manipular conscientemente alguns de seus aspectos culturais e folclóricos.

Portanto, sob o nosso ponto de vista, durante o processo de modernização do espaço agrário da Serra Gaúcha, que, em sua etapa mais recente, tem desencadeado a transformação daquele lugar em espaço de lazer e de turismo, o camponês, apesar de subordinado ao capital, não deve ser encarado como uma simples marionete, que segue à risca, sem nenhuma voz ativa, tudo aquilo que the é imposto. Afinal de contas, não é de hoje que, para conseguir reproduzir seu modo de vida, os colonos produtores de uva têm tido que se adaptar de maneira ativa e criativa às regras que vêm de fora, reinventando-se para preservar-se. Estamos de acordo com Teodor Shanin quando afirma que:

o que realmente se quer dizer é que os camponeses representam uma especificidade de características sociais e econômicas, que se refletirão em qualquer sistema societário em que operem. Quer dizer também que a história camponesa se relaciona com as histórias societárias mais amplas, não como simples reflexo, mas com medidas importantes de autonomia (SHANIN, 1980, p. 69).

Após os breves exemplos indicados neste artigo, podemos concluir afirmando que o movimento de turistificação da porção colonizada por italianos na Serra Gaúcha tem implicado na produção de dois tipos de espaço visando atrair o turista - espaços distintos, mas integrados, tanto em termos de discurso como em termos econômicos. O primeiro é aquele do colono, ligado "ao passado" e ao rural, o outro, aquele das vinícolas, "mais refinado", é responsável por fazer a ponte entre a tradição cultural italiana e a modernidade capitalista. Em ambos, a cultura popular de origem camponesa, a história da imigração e as tradições italianas se fazem presentes, contudo, de acordo com as maneiras pelas quais elas são pensadas e utilizadas, sua materialização se dá de formas bastante distintas.

De maneira geral, é possível afirmar que, ao compreenderem a cultura popular de maneira "folclórico-mercantil" (ou seja, estática, passadista e com vistas à reprodução do capital), as ações voltadas ao turismo acabam por retirar as contradições da história e do espaço, ajudando a construir e divulgar uma imagem homogênea e estereotipada da região, além de estimular a proliferação de simulacros e espaços espetaculares.

Por outro lado, apesar da regra ser quase sempre essa, não é em todas as situações que o 
turismo diz respeito apenas aos simulacros, banalizações e espetacularizações. Quando aliado às demais atividades realizadas no interior da propriedade familiar, por exemplo, ele pode representar uma alternativa econômica interessante aos camponeses, contribuindo para a sua reprodução enquanto pequeno proprietário não-capitalista. Porém, não custa lembrar que para que isso ocorra, é preciso que estes sejam sujeitos ativos do processo (e não meros objetos de decoração) e que o turismo entre como opção e não imposição para o incremento da renda familiar.

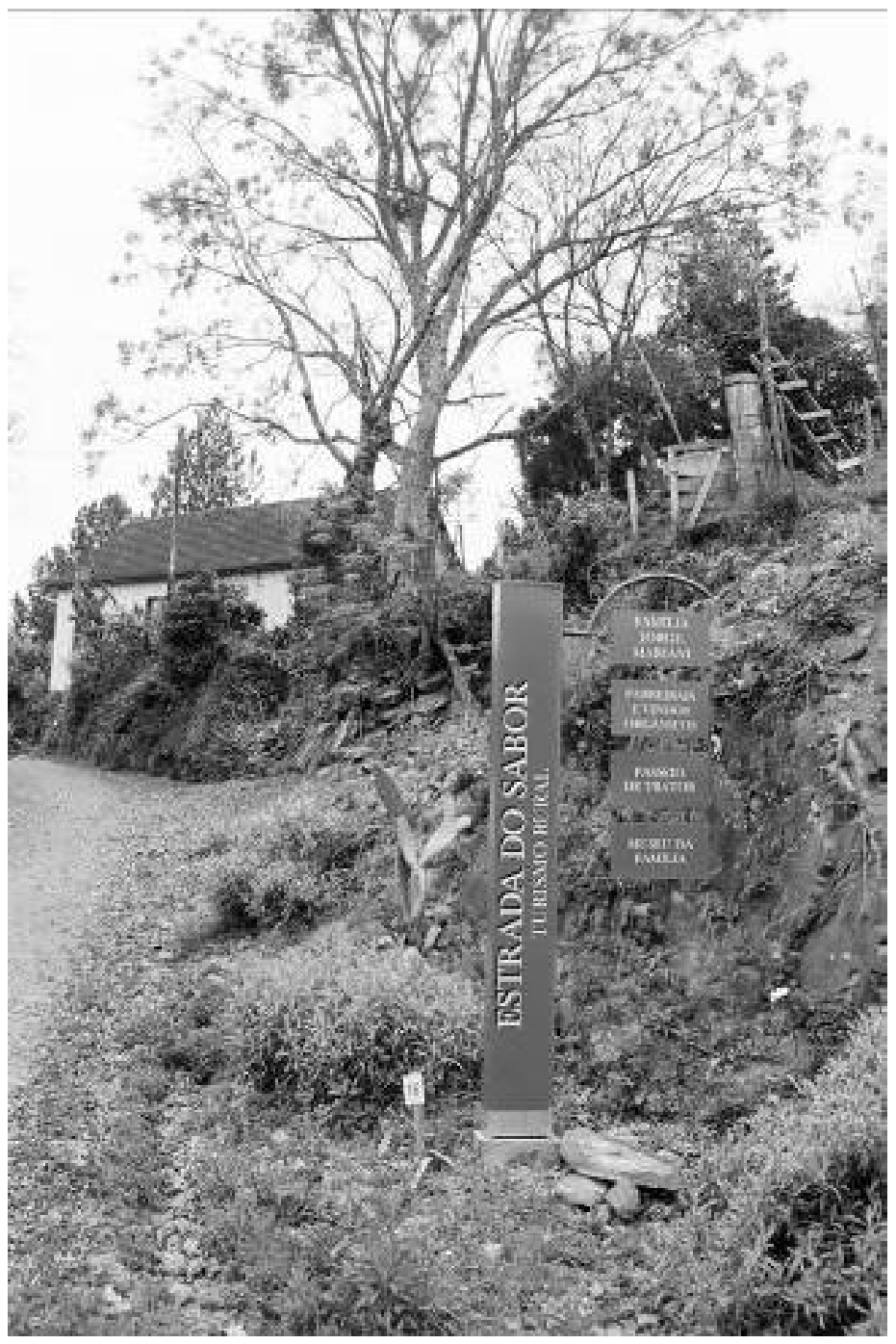

Entrada da propriedade dos Mariani, com placa padronizada do roteiro turístico "Estrada do Sabor" indicando as atrações do local: parreirais e vinhos orgânicos, passeio de trator e museu da família. Foto: setembro/2007, autoria própria. 


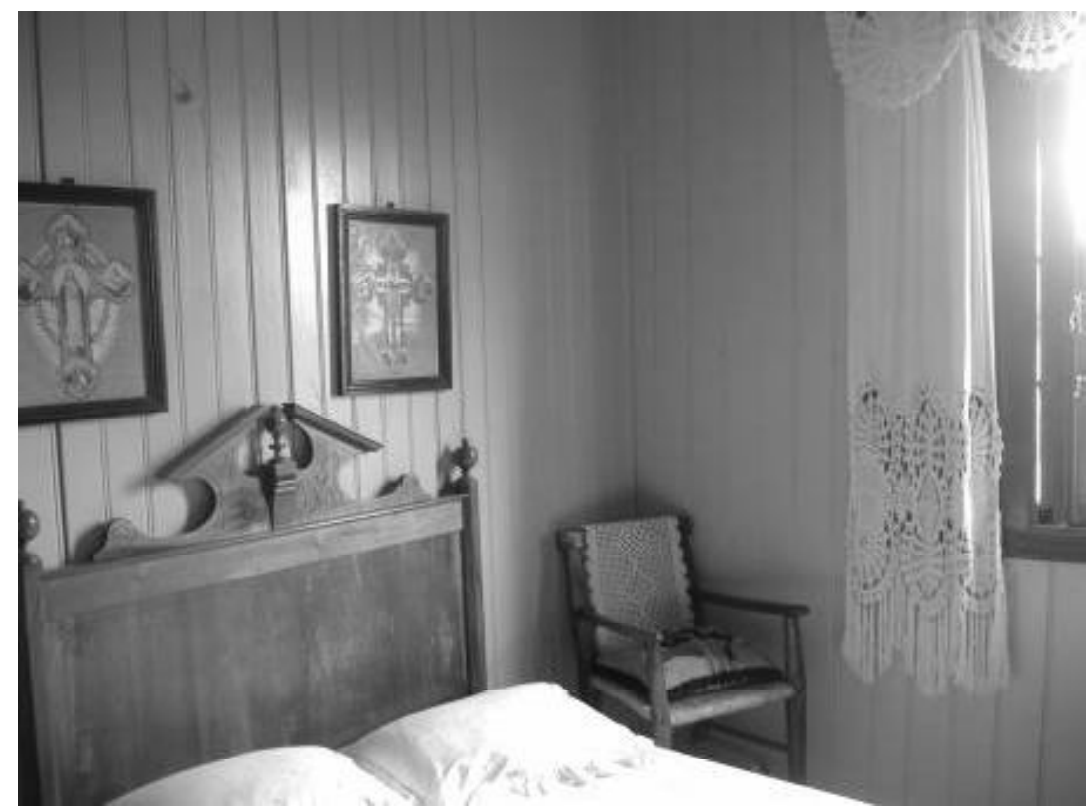

Quarto da "nonna", arrumado e transformado num pequeno museu familiar. Foto: Outubro/2007, autoria própria.

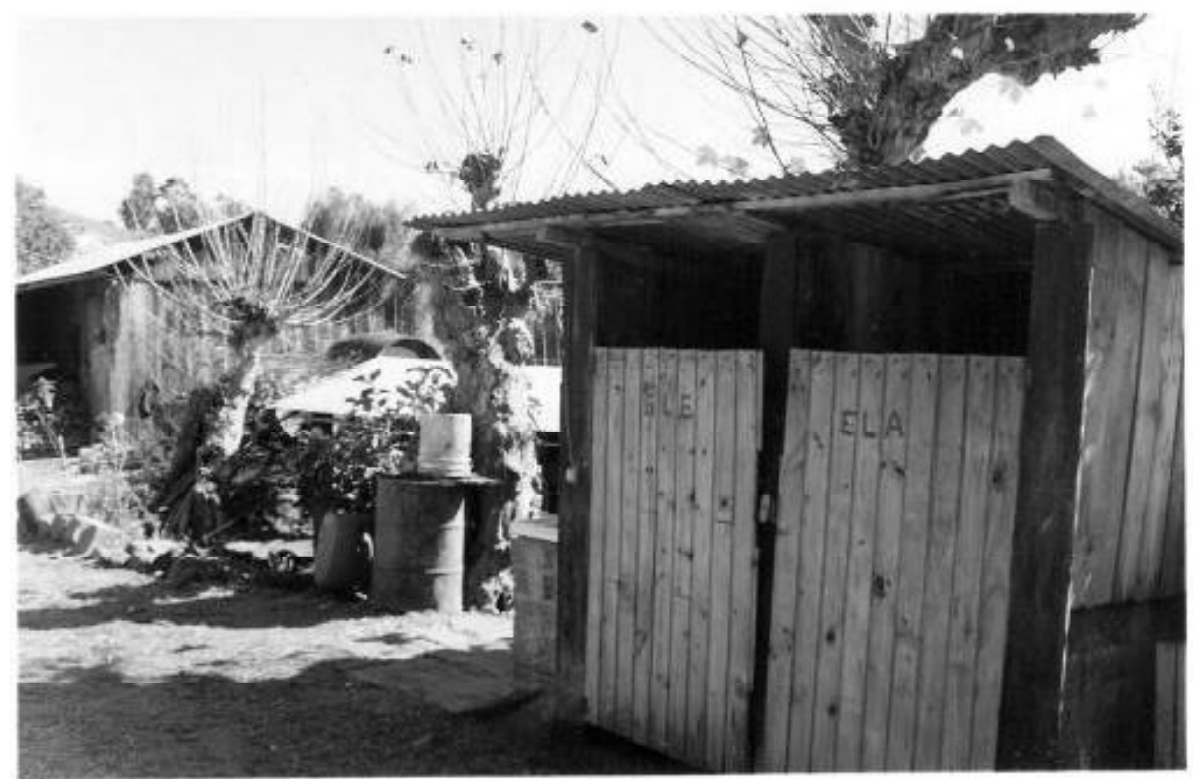

Banheiros masculino e feminino, construídos juntos à propriedade da família para receber os eventuais grupos que por lá chegam. Hoje em dia, a unidade camponesa, para além da produção agrícola e do lugar da morada, também é o locus do turismo. Foto: maio/2006, autoria própria. 
Para finalizar, a transformação de um celeiro em uma espécie de "cenário" expressa um movimento que não é exclusivo da Serra Gaúcha, mas que é comum a diversos outros espaços agrários ao redor do mundo, especialmente naqueles onde predomina a pequena propriedade camponesa, que, nas últimas décadas, com o desenvolvimento capitalista, também têm sido utilizados como espaços de lazer e turismo.

Entretanto, por se tratar de um processo que engendra múltiplos e complexos aspectos, se faz necessário dizer que somente nos foi possível abordar alguns deles, deixando diversos outros (como o caso da recente especulação imobiliária e a valorização mercadológica daquelas terras) para serem analisados e estudados mais profundamente num momento posterior. Espero, porém, que as reflexões aqui apresentadas possam ter contribuído de alguma maneira para um melhor entendimento acerca desta nova etapa do desenvolvimento capitalista na Serra Gaúcha e estimulem outros pesquisadores a realizarem estudos que complementem, dialoguem ou discordem deste, possibilitando assim que o pensamento geográfico esteja sempre em constante movimento e renovação.

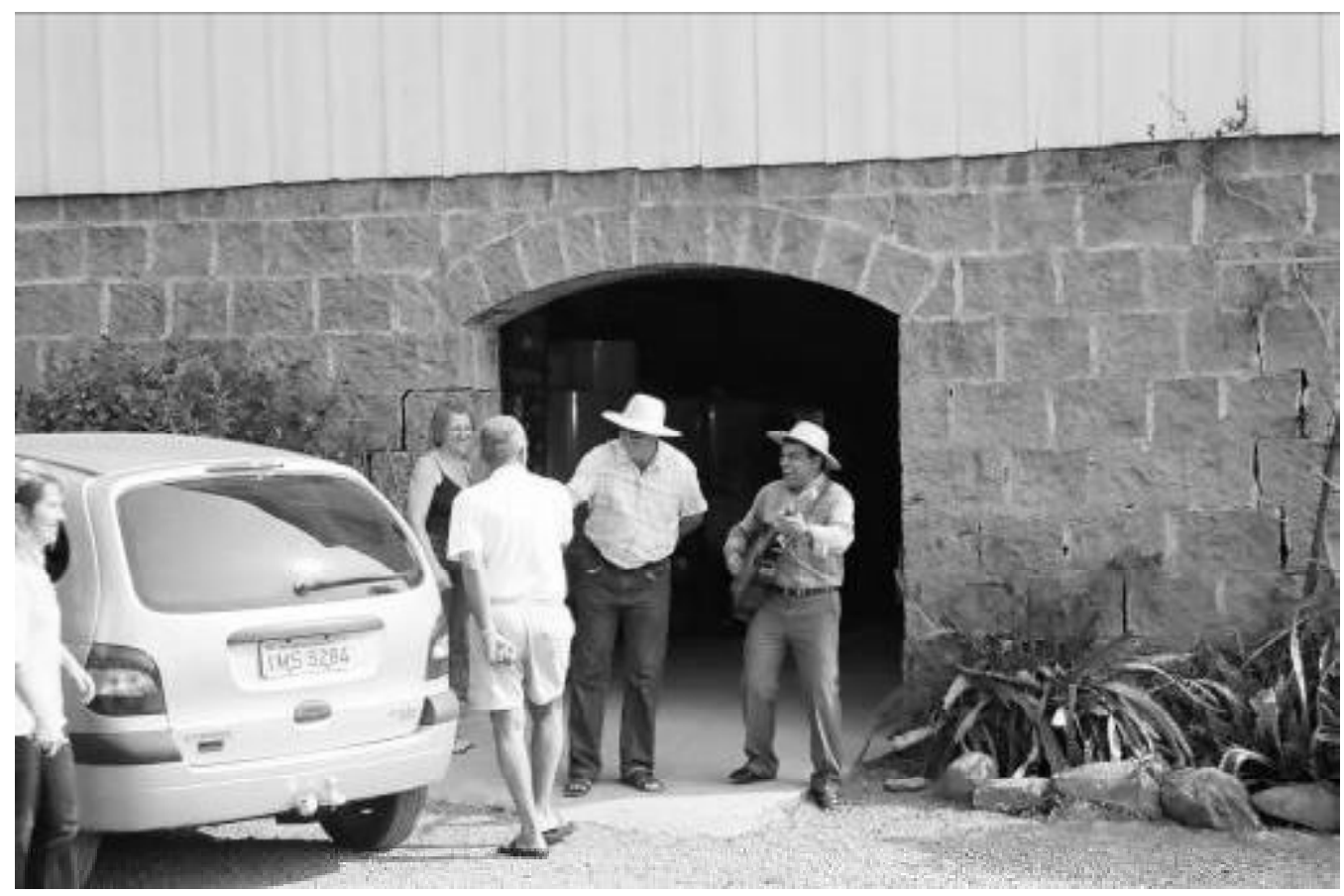

Dia de filmagem na propriedade de Jorge Mariani para o vídeo promotor de Garibaldi. 0 agricultor, longe de ser uma marionete, manipula a imagem que se faz dele em favor de seus interesses. Ao seu lado, um cantor de Bento Gonçalves toca músicas italianas para dar mais "charme" ao filme. Foto: outubro/2007, autoria própria. 


\section{Notas}

${ }^{1}$ Artigo escrito com base em dissertação de mestrado apresentada em agosto de 2008 ao Departamento de Geografia da Faculdade de filosofia, Letras e Ciências Humanas da Universidade de São Paulo (FFLCH - USP) para a obtenção do título de Mestre em Geografia Humana, sob orientação da Profa. Dra. Marta Inez de Medeiros Marques.

2 Situação diferente da ocorrida em alguns municípios serranos de colonização alemã como Gramado e Canela, que desde há muito, decidiram dedicarse ao turismo. Criando cenários que lembram a Europa e fabricando eventos (como, por exemplo, o festival de Cinema de Gramado), estas cidades começaram a atrair um enorme fluxo de visitantes fazendo com que, atualmente, o turismo responda pela geração de boa parte de sua renda.

3 Com base em Marx, Harvey afirma que "a renda monopolista surge porque os atore sociais podem aumentar seu fluxo de renda por muito tempo, em virtude do controle exclusivo sobre algum item, direta ou indiretamente, comercializável, que é, em alguns aspectos, crucial, único e irreplicável" (HARVEY, 2005, p.222).

${ }^{4}$ Com a melhora da qualidade dos produtos e um discurso de singularidade sustentado por estudos e propagandas, em 2002, o Instituto Nacional de Propriedade Industrial (INPI), reconheceu o Vale dos Vinhedos como o primeiro lugar brasileiro a receber Indicação de Procedência para seus vinhos. Em 2007, a Indicação Geográfica Vale dos Vinhedos foi reconhecida pela União Européia.

${ }^{5}$ É importante mencionar que, atualmente, outras áreas de produção de vinhos finos dentro ou fora da Serra Gaúcha, seguindo o exemplo do Vale dos Vinhedos, têm buscado elementos que possibilitem valorizar seus produtos e diferenciá-los em relação aos seus concorrentes. Na Campanha Gaúcha, por exemplo, o discurso da localidade é buscado no fato do lugar estar localizado no "paralelo 31 " onde, os terrenos abertos e ventilados dos pampas, somado aos bons índices de insolação, fariam deste um dos melhores lugares do mundo para a fabricação de vinhos finos.

${ }^{6} \mathrm{~A}$ maior parte destes trabalhos e etnografias escritos sobre os colonos ítalo-brasileiros da Serra Gaúcha, sobretudo aqueles elaborados até a década de 1950, reproduziam a ideologia da elite burguesa surgida no momento da industrialização da Zona Colonial Rio-Grandense no início do século XX e que precisava contar sua história para tomar assento e se firmar politicamente no cenário gaúcho.

7 Disponível em: <http://www.valedosvinhedos.com.br>. Acessado em novembro de 2007

${ }^{8}$ Não menosprezamos o fato de que se trata de um lugar diferenciado em relação a outros no país, uma rápida olhada nas estatísticas mostra isso, mas daí a afirmar que estamos "na Europa" ou que não existe pobreza há um grande abismo.

${ }^{9}$ Ainda assim, não custa repetir que a terra, no caso dos italianos, já era mercadoria e que essa "reforma agrária" contemplava apenas os pequenos agricultores brancos, deixando de lado os caboclos e negros.

${ }^{10}$ Ver Tavares dos Santos (1978).

${ }^{11}$ Estes camponeses formaram uma das bases sociais de origem do Movimento dos Trabalhadores Rurais Sem-Terra (MST). Para saber mais a respeito, ler Maestri in Stedile (2005).

${ }^{12}$ Segundo este discurso, por exemplo, a pobreza dos muitos colonos e a riqueza de alguns outros não são vistas, de maneira geral, como produtos de um sistema injusto e sim como fruto da preguiça e azar de uns e esforço e sorte de outros.

13 "O espetáculo é a ideologia por excelência, porque expõe e manifesta em sua plenitude a essência de todo sistema ideológico: o empobrecimento, a sujeição e a negação da vida real" (DEBORD, 2003, p. 138).

${ }^{14}$ Segundo Harvey: "A inclinação pós-moderna de acumular toda a espécie de referências e estilos passados é uma de suas características mais presentes" (HARVEY, 2000, p. 85).

15 Disponível em: <http://www.brasilviagem.com>. Acessado em outubro de 2007.

16 "Sideways - entre umas e outras", filme dirigido por Alexander Payne, EUA, 2004. Na história, dois 
amigos passam um fim de semana conhecendo vinícolas, degustando vinhos e passeando entre os vinhedos do Vale de Santa Ynez, outro grande pólo vinícola californiano, localizado em Santa Bárbara.

17 Conceito elaborado durante a Oficina Regional de Turismo Rural na Agricultura Familiar, em Belo Horizonte - MG (2003), pela Rede de Turismo Rural na Agricultura Familiar - Rede TRAF e adotado pelo Ministério do Desenvolvimento Agrário.
18 "O capitalismo acostumou-nos a enxergar a cultura do povo através de um espelho retrovisor" (CANCLINI, 1983, p. 107).

19 "Garibaldi 107 anos - Orgulho de ser daqui". Disponível em: <http://www.youtube.com>. Acessado em Abril de 2008.

20 Natalina Vaccaro, participante do roteiro "Estrada do Sabor", em depoimento no vídeo sobre o município de Garibaldi.

\section{Referências Bibliográficas}

ALFREDO, A. Geografia do turismo - A crise ecológica como crítica objetiva do trabalho. O turismo como "ilusão necessária". GEOUSP Revista da pós-graduação em Geografia, São Paulo, n. 9, p 37-62.

APROVALE. Associação dos Produtores de Vinhos Finos do Vale dos Vinhedos. Disponível em: <http://www.valedosvinhedos.com.br. Acessado em novembro de 2007.

BOURDIEU, P. O Poder Simbólico. Rio de Janeiro: Bertrand Brasil, 1989.

\section{0.}

. Coisas Ditas. São Paulo: Brasiliense,

CANCLINI, N.G. As culturas populares no capitalismo. São Paulo: Brasiliense, 1983.

2004.

. Culturas híbridas. São Paulo: Edusp,

CARLOS, A. F. O lugar no/do mundo. São Paulo: Hucitec, 1996.

Espaço-tempo na metrópole - a fragmentação da vida cotidiana. São Paulo: Contexto, 2001.

CARLOS, A. F.; DAMIANI, A. L.; SEABRA, O. C. L. (org.) O espaço no fim de século - a nova raridade. São Paulo: Contexto, 2001.

DEBORD, G. A Sociedade do Espetáculo. Rio de Janeiro: Contraponto, 2003.

FALCADE, I.; MANDELLI, F.(org.) Vale dos Vinhedos: caracterização geográfica da região. Caxias do Sul: EDUCS, 1999.
FÁVERO, I. M. R. Planejamento Municipal: Do turismo para o desenvolvimento (sustentável). 2004. Dissertação (mestrado em turismo) Universidade de Caxias do Sul, Caxias do Sul, 2004.

HARVEY, D. Condição pós-moderna. São Paulo: Edições Loyola, 2000.

. A produção capitalista do espaço. São Paulo: Annablume, 2005.

HENRIQUES, E. B. A Lisboa Turística: entre o imaginário e a cidade. Lisboa: Editora Colibri, 1996.

PERALTA, E. O mar por tradição: o patrimônio e a construção das imagens do turismo. Horizontes Antropológicos, Porto Alegre, n.20, p 85-96, 2003.

PRODETUR SUL. Programa de desenvolvimento do turismo no sul do Brasil. Relatório de avaliação e gestão ambiental e social programática. Disponível em: <http://www.scp.rs.gov.br/ uploads/informeambientalsocial1.pdf $>$. Acesso em novembro de 2007.

SANTOS, J. T. dos. Colonos do Vinho. São Paulo: Hucitec, 1978.

SHANIN, T. A definição de camponês: conceituações e desconceituações - o velho e o novo em uma discussão marxista. São Paulo/ Petrópolis: Cebrap/Vozes, 1980.

TODESCHINI, M. o Vale da Felicidade. Revista Veja. Disponível em: <http:// www.veja.abril.com.br/101007/p 110shtml>. Acessado em dezembro de 2007. 
TOMAZZONI, E. L. Análise do discurso turístico da Serra Gaúcha. In: Em Questão, Porto Alegre, v.12, n.2, p.339-365, jun/dez. 2006.
YUDICE, G. A conveniência da cultura: usos da cultura na era global. Belo Horizonte: Ed. UFMG, 2004.

Trabalho enviado em outubro de 2009

Trabalho aceito em dezembro de 2009 